\title{
ENTRE GAFANHOTOS E VAGA-LUMES: \\ A POTÊNCIA NARRATIVA NA CRIAÇÃO DE OUTROS IMAGINÁRIOS POLÍTICOS NA \\ Praia da Estação
}

\author{
BETWEEN LOCUSTS AND FIREFLIES: \\ narrative power in the creation of political imaginary in the Praia da Estaçáo \\ Milene Migliano \\ Universidade Federal da Bahia, Programa de Pós-Graduação em Arquitetura e Urbanismo, Salvador, Bahia, Brasil
}

R E S U M O : Buscamos, neste artigo, realizar uma montagem de narrativas de situaçôes vivenciadas na experiência insurgente Praia da Estação a partir de 2010, em Belo Horizonte, Minas Gerais. Partimos do questionamento de Ana Clara Ribeiro Torres (2011) sobre a novidade, com o uso da Internet, das mobilizaçóes de resistência política urbana e a capacidade delas de superar a contenção do imaginário politico. Por meio de três narrativas imagéticas de eventos - o primeiro Eventão; o aniversário de um ano da experiência, com a chegada do mar na praça; e a lavagem das escadarias do edifício da prefeitura, durante o bloco de carnaval da Praia da Estação -, pretendemos tensionar os processos de produção de sentidos, tentando desvelar detalhes e conexóes de fabulação de imaginários diferentes daqueles que circulam na contemporaneidade do planejamento urbano.

P A L A V R A S - C H A V E : Belo Horizonte; Praia da Estação; espaço público; narrativa; imaginários políticos; experiência urbana.

A B S T R A C T : With this article we intend to create a montage of narratives in situations experienced during the Praia da Estação (Station Beach) insurgence, which started in 2010, in the city of Belo Horizonte, in Minas Gerais, Brazil. We started from the questioning and problematzation of overcoming the contention of the political imaginary $(R I B E I R O, 2011)$ in relation to the results achieved by the movements of political resistance, such as Praia da Estaçáo. It is our intention to tighten the production processes, attempting to expose details and connections to other imaginaries, through the events of three imagetic narratives: the first big event, the first anniversary of the experience with the arrival of the sea in the square, and washing of steps of the City Hall during the Praia da Estação carnival block.

K E Y W O R D S : Belo Horizonte; Praia da Estação; public space; narrative; political imagination; urban experience.

DOI: https://doi.org/10.22296/2317-1529.2016v18n2p240 
Este artigo pretende compor uma montagem de algumas situaçóes insurgentes vividas durante a realização da Praia da Estação, em Belo Horizonte. A proposta é produzir uma montagem, a partir de narrativas que evidenciam temporalidades distintas, da experiência urbana na ocupação de territórios urbanos. Partindo desse recorte, tensionamos as situaçôes a fim de compreender se é possível ultrapassar a contenção do imaginário político contemporâneo. De acordo com Ribeiro (2011), para de fato transformar a realidade social, são necessários não apenas bons resultados em uma batalha insurgente, mas também a ampliação da imaginação a respeito do que podemos fazer em nosso meio de vida.

A Praia da Estaçáo foi mobilizada em janeiro de 2010, a partir de uma reunião presencial convocada em um blog ${ }^{1}$ anônimo na Internet, depois que o prefeito da capital decretou que estavam proibidos eventos de qualquer natureza na Praça da Estação. No dia da reuniáo, cerca de 80 pessoas estiveram reunidas na praça, vestidas de branco, preto e vermelho, conversando sobre o lugar de onde vinham, as ideias que traziam, os caminhos que, juntos, poderíamos seguir. Depois de algumas horas, a conclusão foi a de que não era mesmo razoável ter, entre nós, apenas opinióes em comum; éramos muito diferentes, mas havia um motivo para estarmos ali, e decidimos fazer algo a respeito. Fizemos uma lista de e-mails, e, em uma semana, estava anunciada a chamada para a primeira Praia na Estação, marcada para a manhã de um sábado, especificamente no dia 16 de janeiro de 2010.

Os fragmentos de narrativas que abordaremos aqui provêm de situaçôes em que as possibilidades de ocupação de espaços urbanos abandonados, revitalizados e/ ou expropriados foram reivindicadas pela prática dos cidadãos, visando a propostas urbanísticas diferentes daquelas do poder hegemônico. A ideia inicial de fazer acontecer uma praia no centro da cidade foi escolhida pelo simples motivo de que qualquer um saberia o que fazer em uma praia, e, assim, estaríamos acionando a participação e a memória de todos na composiçáo da situação. Outro fato importante: a primeira condição para que a praia realmente acontecesse foi, em alguma medida, uma inversão das regras e dos bons costumes da tradicional família mineira, apoiados na moral da Igreja Católica, amparada em irmandades e coronelismos - todos trajariam biquinis, sungas ou maiôs de banho.

Entre as diversas maneiras de fazer uso do espaço público da Praça da Estação, tentaremos apresentar aquelas em que identificamos a produção de narrativas sobre a Praia. Destacamos, inicialmente, o teaser da Praia da Estação que, lançado logo após a primeira praia, fazia um convite para os próximos eventos com um funk endereçado: "se liga aí prefeito/ aqui não tem depredação/ não me proíbe de ser cidadão/ liga a cascata, bota o calção e vem pra praia da estação." ${ }^{2}$ Depois aconteceu o primeiro Eventão, em um domingo, fazendo transbordar pela primeira vez a Praia para além da Praça da Estação. Por sua vez, a marchinha, o trajeto e a lavagem da escadaria do edifício da prefeitura no primeiro ano do bloco da Praia da Estaçáo compóem a produção do Bloco da Praia da Estação, realizado desde 2010 nos sábados de carnaval na capital. Outras situaçóes guardam a exclusividade de uma realização contextual e êfemera, como a fabricação do mar para o Eventão ${ }^{3}$ de aniversário de um ano da Praia. Outras situaçóes ainda, como os mandados de desocupação pela cidade, utilizam-se da convocação da ideia da Praia para juntar forças e motivação em contextos relacionados à luta por moradia urbana, como aconteceu, recentemente, na Ocupaçáo Izidora, ameaçada de despejo pela prefeitura, também no mandato de Márcio Lacerda.
1 Disponível em: <http:// vadebranco.blogspot.com. br>. Acesso em: 28 jun. 2016.

2 Disponivel em: <https:// www.youtube.com/ watch?v=4mEzQrF6v0M> Acesso em: 31 ago 2015.

3 Eventão é o nome que foi dado à criação de outro encontro, não apenas nos sábados de sol, na Praia da Estação. Esses encontros continham uma programação cultural ampliada e buscavam, no título, ironizar a proibição de eventos do prefeito. 
4 A partir da reunião que aconteceu pela chamada no blog anônimo no início de 2010, foi produzida uma lista de e-mails; depois da primeira praia, os banhistas - como se auto-declaram os manifestantes da Praia da Estação - decidiram produzir um blog de acesso irrestrito às postagens, no endereço virtual www.pracalivrebh wordpress.com.
5 Seguindo a análise de Carolina Abreu (2013) na dissertação Ei polícia, a praia é uma delícia rastros de sentidos nas conexões da Praia da Estação, esse período foi um daqueles em que houve maior mobilização e trocas nos dois ambientes das redes sociais.

6 Disponível em: <www. pracalivrebh.wordpress $>$. Acesso em: 30 ago. 2015. Até 30 de agosto de 2015, o espaço continuava aberto.
Temos acompanhado na internet ${ }^{4}$, por meio de uma etnografia digital, todas essas situaçóes, e podemos dizer que a busca por respostas para as condiçóes de possibilidades de as novas tecnologias de comunicação e informação associadas à Internet transformarem as experiências de movimentos insurgentes na cidade é motivadora, além de fazer-nos visualizar muitos dissensos. No início de 2015, uma discussão acirrada sobre a legitimidade da chamada pública da Praia da Estação no site de redes sociais Facebook provocou a emergência de situaçôes de desrespeito, machismo e racismo, tanto na Internet quanto no espaço físico. A situação estava primeiramente relacionada a um desentendimento sobre os tipos de referências culturais da ocupação - questionamento que surgiu depois da públicação no site de um cartaz de chamada da retomada da Praia no verão desse ano. Algumas pessoas se mobilizaram para produzir e postar um cartaz, que foi criticado por outra pessoa de maneira preconceituosa, deslegitimando o trabalho; a crítica foi rapidamente rechaçada com diversas publicaçóes que remetiam ao racismo e a uma certa elitização da Praia: o grupo novo (aquele criticado) questionava a hierarquia que parecia existir, como se houvesse a necessidade de submeter os chamados a alguém. Logo, outros adeptos da mobilização retomaram a importância da diversidade e da mobilidade em relação aos que estavam à frente das ações, ressaltando a horizontalidade e a ausência de lideranças.

Lembramos que, já durante o primeiro ano, em 2010, a chamada e ocorrência da Praia do Trabalhador, no primeiro de maio, surgiu por via de um desconhecido dos banhistas da Praia, o que gerou uma grande discussão dentro da lista de e-mails e do blog da Praia da Estaçấo. Ambos os ambientes virtuais eram consideravelmente utilizados na época'; e, depois de algumas discussōes - tanto nos espaços virtuais como em encontros na Praia -, chegamos à conclusão de que era exatamente essa liberdade de ação que gostaríamos que emergisse do esforço em se manter o $b \log ^{6}$ como um espaço aberto, com login e senha para a publicação disponíveis na primeira página. Segundo Carolina Abreu (2013), nos ambientes virtuais analisados em sua dissertação, as maiores discussóes sempre giraram em torno da horizontalidade e do fato de a Praia ser um espaço sem líderes; tais questôes ainda continuam tendo reverberaçôes, mesmo depois de cinco anos. Pelo exposto até o momento, já podemos, em alguma medida, inferir que a Praia da Estação possibilitou um aumento das discussōes sobre questóes que enfatizam modos diferentes de fazer a cidade.

\section{OUTRAS TEMPORALIDADES}

A praça Rui Barbosa é conhecida em Belo Horizonte como Praça da Estação, já que abrigava, até 2004 , a estação de trem e a central de metrô. Nesse ano, o prédio entrou em reforma para receber o acervo da Fundação Cultural Flávio Gutierrez, que, atualmente, compõe o Museu de Artes e Ofícios. A Praça da Estação tem lugar cativo na memória e história da cidade, pois foi a porta de entrada na nova capital mineira, tanto no que diz respeito à chegada de pessoas quanto de materiais. Belo Horizonte foi inaugurada em 1896, e, em 1904, a praça já estava urbanizada, contendo o "primeiro relógio público da cidade" , que havia sido fixado na estação antiga em 1898. Em 1922, foi feito o novo prédio da Estaçáo, projeto do arquiteto italiano Luiz Olivieri, que estava na cidade desde 1895, compondo a Comissão Construtora para a Nova Capital, na equipe responsável pela execuçáo do plano de Aarão Reis. É importante 
ressaltar, ainda, que a nova capital foi uma das primeiras cidades planejadas no Brasil e que o plano original, quando produzido, foi inspirado no positivismo francês, o qual não considerava conhecimentos ligados a crenças e espiritualidades, mas sim à ciência e aos avanços científicos, compreendidos como único modo de progresso do homem.

Além do novo prédio, a praça também ganhou, em 1922, estátuas representando as quatro estaçôes e um tratamento paisagístico inspirado nos jardins franceses, uma vez que, até aquele tempo, os jardins da cidade seguiam a tradição inglesa. Em 1931, foi inaugurada uma fonte luminosa, ampliando as atraçốes oferecidas aos habitantes e visitantes da cidade, como o jardim com mais de 250 espécimes diferentes de rosas. $\mathrm{Na}$ década de 1960, ocorreu a ampliação da Avenida dos Andradas, com a consequente diminuiçáo da área para convivência, isto é, para uso dos pedestres, nos nichos da praça.

Sabemos que, com o desmantalamento da rede ferroviária nacional, a dimensáo de entrada e saída da cidade vai tomando outro plano; em 1980, a praça foi novamente tema de polêmica sobre os usos a oferecer: os planejadores almejavam instalar a estação central de metrô superficial junto à estação de trens.

Em 1988, o prédio da estação foi tombado, e, em 1998, o conjunto arquitetônico da Praça da Estação passou a integrar a lista de bens culturais do Estado de Minas Gerais. Nesse momento, o metrô já estava instalado, transformando a sociabilidade da praça em, novamente, um lugar de "aportamento de passageiros" (RODRIGUES, 2012, p. 210), mas, dessa vez, não mais para pessoas provenientes de outros lugares, agora a maioria era oriunda da Regiấo Metropolitana de Belo Horizonte.

Seguindo, ainda, a trajetória de espaço público da Praça da Estação, encontramos informaçóes de que a área foi amplamente usada pelo movimento das Diretas Já, no início da década de 1980, e de que em 1996 "as edificaçóes da Praça eram de uso coletivo, uso comercial, de serviços e industrial. $\mathrm{O}$ espaço abrigava grande número de manifestaçōes culturais. À época havia um bar localizado no prédio da Estação Central" (RODRIGUES, 2012, p. 208). Em 2002, a praça entrou em um processo de revitalização que havia começado com a retirada da área de estacionamento em frente ao prédio da estação. Depois, veio o deslocamento das estaçóes: a do metrô, para um hall subterrâneo rapidamente adaptado, e a de trem, para um prédio em péssimo estado de conservação. Na sequência, houve a retirada dos comerciantes e dos outros usos públicos do prédio.

Em 2005, as porções da praça à oeste da margem do Ribeirão Arrudas tiveram seus espaços públicos tapados, e, a partir de um certo dia, todas as árvores passaram a portar números e letras em pequenos papéis cor-de-rosa amarrados aos seus troncos; parecia que estavam marcadas para alguma decisão entre morte ou vida. A praça entrou em reforma. Todas as pessoas que a utilizavam para almoçar, encontrar, trabalhar - como os fotógrafos lambe-lambe e os vendedores de sorvete e CD's -, descansar, esperar o ônibus ou simplesmente para trafegar ficaram impossibilitadas de realizar seus usos no território.

O deslocamento da estação de trens e metrôs foi feito com a promessa de que, assim que o museu se estabelecesse, as plataformas de passageiros voltariam para o lugar original e as pessoas transitariam pelas obras do acervo para chegar aos vagóes. Em 2005, a polêmica chegou aos muros dos tapumes das obras na escadaria que liga a Rua Sapucaí à praça, os quais foram preenchidos com inscriçóes que criaram uma rede de sentidos sobre o direito de ser informado quando o museu ficaria pronto. Durante a reforma, as estátuas que ainda estavam na praça foram substituídas por réplicas e as 
8 Diz a máxima: "em Belo Horizonte não tem mar, tem bar".

9 Termo utilizado por Paulo Rocha, banhista da praia, citado por Thalita Melo (2014) e Igor Oliveira (2012).

100 conjunto Governador Juscelino Kubitschek foi projetado por Oscar Niemeyer e construído na década de 1950. Localiza-se no bairro Santo Agostinho, próximo à Praça Raul Soares. No período de sua construção, o objetivo do governador era atenuar a crise de moradia da classe média, como consta na página oficial da cidade. 0 projeto ambicionava conter todos os serviços no próprio conjunto, refletindo a prática dos complexos arquitetônicos modernos europeus, inspirados nos ideais de Le Corbusier (Disponivel em: <http:// www.belohorizonte.mg.gov. br/node/33144>. Acesso em: 30 ago. 2015).

11 Informações disponíveis em uma entrevista constante em Cesário (2011). originais foram guardadas no Museu Histórico Abílio Barreto, sob decisão do Poder Público para protegê-las de vandalismo.

Mas os belo-horizontinos não sofriam apenas com a falta da praça pública, eram afetados também pela falta de praia ${ }^{8}$. Em 1989, atores do Grupo Galpão convidaram bailarinos e atores de vários grupos da cidade para saírem vestidos com roupas de banho pela Savassi e Praça Sete, com faixas, proclamando o manifesto "Queremos praia!" (OLIVEIRA, 2012, p. 216), a partir do qual promoveram o imaginário de que "todos [poderiam] se torn[ar] participantes ativos da experiência, do evento" (MELO, 2014, p. 23). A experiência, fruto de um Festival de Inverno da Universidade Federal de Minas Gerais (UFMG), é considerada como uma das mais importantes na formação do Grupo Galpão, tanto no que tange ao uso do espaço, quanto na "relação ator/expectador" (GONTIJO, 2009 apud MELO, 2014, p. 23).

Outro evento relacionado ao imaginário praieiro9 foi a ideia do grupo Maneiras de Morar (MOM), da Escola de Arquitetura da UFMG, de criar uma praia em um lote vago da cidade, ocupando-o com propostas diversificadas de uso. No lote-praia, foram espalhados espreguiçadeiras, piscinas de plástico e guarda-sóis, que foram aproveitados durante um dia inteiro, como pode ser visto no vídeo-registro da ação.

Já em 2008, Márcia Amaral, moradora do Edíficio $\mathrm{JK}^{10}$, passou a usar a praça Raul Soares para tomar banho de sol, deitada em uma canga que estendia ao lado de seus acessórios para usufruir de um momento ao ar livre, próximo às fontes de água. Além de ter sido tema da mídia belo-horizontina, por chamar a atenção dos transeuntes e outros adeptos da praça, Márcia começou a sofrer também repressão policial por estar na grama do espaço público. No mesmo ano, a musa da Raul Soares, como passou a ser chamada, foi presa por desacato às autoridades policiais. Ela reivindicava a liberação do uso do gramado da praça para famílias e para a realização de piqueniques, como acontece em muitas cidades européias na primavera e no verão.

As performances A Ilha (2008), do Conjunto Vazio, e Rotatória de Praia da Estação (2009), do Coletivo Azucrina, também podem ser elencadas, conforme Oliveira (2012) e Melo (2014), como açôes que precederam e influenciaram a escolha da realizaçáo do protesto-festivo como praia, depois da reunião do Vá de Branco. Ambas as açôes conduziam momentos de lazer em rotatórias e outros espaços vagos na cidade, com roupas de banho, cadeiras, guarda-sóis e até cangas. O Rotatória de Praia na Praça da Estação comemorou três anos do Coletivo Azucrina e contou até com sonorização de DJ's. A presença de integrantes de ambos os coletivos na reunião do Vá de Branco possibilitou que a ideia fosse relembrada, apresentada e tomasse forma na primeira Praia da Estaçáo, em janeiro de 2010.

Em 2007, a praça foi novamente entregue ao uso da populaçáo, com a esplanada concluída, fontes de água que saltavam do chão para amenizar o calor da aridez do piso; sua amplidão possibilitava, inclusive, a realização de grandes eventos, seguindo o projeto de lei que havia sido publicado para fazer jus a todas as obras que estavam sendo conduzidas. Quando o uso da praça foi novamente liberado para os habitantes de Belo Horizonte, o pessoal do Duelo de MC's passou a se reunir perto da estátua, retomando a região central para encontros dos adeptos do Hip Hop. Na verdade, os rappers tentaram se reunir aí, mas, como os guardas municipais disseram que precisariam de uma autorização para permanecer no local, passaram a se encontrar na calçada ao lado, o que acabou facilitando a instrumentaçáo para a realizaçáo das rimas, com o uso do som do carro de um dos participantes ${ }^{11}$. Nos primeiros meses, 
eles se reuniram nesse ponto, porém, com a chegada das chuvas, deslocaram-se para a parte de baixo do viaduto Santa Tereza.

Ao final de 2009, após três anos de inauguração do Museu de Artes e Ofícios, a população já tinha percebido que o uso original como estação do prédio desenhado por Luiz Olivieri não voltaria para os usuários do metrô urbano e trem de passageiros ${ }^{12}$. Então, saiu o anúncio de que o decreto que proibia os eventos no espaço público da praça entraria em vigor no primeiro dia de janeiro de 2010 .

É importante assinalar que a discussão sobre os espaços públicos é densa e extensa, demandando um tratamento adequado, no entanto, neste texto, apenas tateamos esse debate. Em uma rápida avaliação das situaçôes já elencadas, como a substituição das estátuas por réplicas, a tomada da função pública do prédio da estação e, por último, a proibição de eventos no espaço público da praça, podemos concluir, em concordância com o que diz Manuel Delgado (2014), que o espaço público está sendo sequestrado pelos discursos que criam a ilusão de continuar proporcionando o poder dos dominadores sobre os dominados, numa tensão que fantasia a potência dos cidadãos como usuários dos espaços, praticamente como clientes do Estado: "A sociedade democrática seria assim, de fato, uma amplificação universal da ideia matriz de sociedade anônima mercantil, cujos individuos participam em função não de sua identidade, mas no entanto compartilham - em um sentido agora empresarial - interesses, ações e valores." (DELGADO, 2014, p. 50).

A cidade ordenada conforma-se, entáo, como uma expressão dos poderes hegemônicos nos espaços públicos. Compreendemos que tal entendimento do espaço social aproxima-se do pensamento de Jacques Rancière (1996) sobre a dimensão política e a ordem policial que regem a realidade social. Para o autor, o mundo social faz uma articulação entre uma ordem policial, que aloca os sujeitos em grupos de nascimento, lugar conquistado e interesses - sujeitos que têm suas funções, espaços ocupados e seus modos de ser articulados em um mundo visível -, e uma ordem política, que dá visibilidade a alguns dos danos sofridos pelos sujeitos que não estão situados na contagem feita pela ordem policial. Para Rancière, "a política é descrita como uma ruptura específica da lógica imposta pela ordem policial”, explica Marques (2012, p. 1), esmiuçando a perspectiva do filósofo, na qual a ocorrência da política acontece quando há perturbação da ordem policial. Essa pertubaçáo ocorre quando, por meio de açôes comunicativas conflituosas, apresenta-se e questiona-se um dano social de minorias/maiorias. Seguindo Rancière, há um comum saturado produzido pela ordem policial, que opera pela via dos consensos, da adequação dos corpos, vozes, intençốes e lugares. Esse tipo de comum náo tem a capacidade de incorporar excessos ou partes que não estáo integradas à sua ordem. Mas a igualdade da ordem policial pode ser questionada a qualquer momento por aqueles que se dáo conta de que náo fazem parte da contagem que ela abrange, embora continue, ainda assim, regendo-os. Ao instaurar um processo de encenação do dano político que sofrem, os sujeitos podem produzir uma cena de dissenso, na qual conquistam esclarecimento e visibilidade do dano e, ao mesmo tempo, sofrem juntos a compreensáo da desigualdade existente nas situaçóes sociais e da naturalizaçáo que se reafirma pelo preconceito e pela injustiça. Rancière ainda destaca que essa cena de dissenso é dissolvida na ordem policial, após conquistada a visibilidade e a transposição do dano que certo grupo social sofria. A política existiria, assim, apenas como um lampejo, brilhando, rápida, mas infimamente, na ordem policial.
12 A linha de transporte de passageiros entre Belo Horizonte e Vitória é uma das últimas ainda preservadas em toda a rede brasileira. Passa pelo Vale do Aço e Governador Valadares, atendendo uma população carente do interior. 


\section{OUTRAS NARRATIVAS?}

Talvez possamos afirmar que a superação da contenção do imaginário político pode vir a acontecer quando um dos lampejos que irrompem a ordem policial brilha e produz narrativas da experiência. Se urbana, a narrativa precisa, para existir, vir a ser compartilhada nas redes de sentidos espalhadas pela(s) cidade(s), a fim de que produza imaginários outros sobre as experiências vividas. A compreensão da narrativa urbana é atravessada pela dimensão da escrita da cidade. Em Rua de Mão Única, Benjamin (2000 [1928], p. 28) anuncia que os textos, as "nuvens de letras-gafanhotos", que, antes se encontravam deitados nos livros, passariam a ocupar a posição ereta, distribuídos pelos muros, atrapalhando o contato com o sol dos "espíritos dos habitantes da metrópole" (BENJAMIN, 2000 [1928], p. 28). Nos tempos do historiador, as letras que ocupavam as ruas eram os nomes dos estabelecimentos comerciais, e a premonição benjaminiana de que elas iriam se tornar cada vez mais densas virou realidade. Agora, no século XXI, é fato que a quantidade de estímulos urbanos e a velocidade do transporte transformaram as condiçôes de vida e, consequentemente, de possibilidade de se produzir narrativas.

Em Teses sobre a História, Benjamin (1996 [1940]) trata da emancipação que as narrativas da história são capazes de promover com a cisão do pensamento histórico oficial, isto é, o pensamento dos vencedores. Assim, compartilhamos o entendendimento de que "o cronista que narra os acontecimentos, sem distinguir entre os grandes e os pequenos, leva em conta a verdade de que nada do que um dia aconteceu pode ser considerado perdido para a história” (BENJAMIN, 1996, [1940], p. 223). Nesse sentido, a ampliação das narrativas comporia uma possibilidade de ampliação do imaginário político por meio da fabulação e fabricação de outras experiências urbanas insurgentes, ainda nem sequer sonhadas e que podem vir a ser meios de transpor a produção do "terror inconsciente que malogr[a] qualquer apelo à organização da resistência” (BENJAMIN, 2013, [1925], p. 70). O perigo da desistência da resistência é abrangido por outro ainda maior: "entregar-se às classes dominantes, como seu instrumento" (BENJAMIN, 1996 [1940], p. 223). A opção sugerida pelo o autor é "apropriar-se de uma reminiscência, tal como ela relampeja no momento de um perigo" (BENJAMIN, 1996 [1940], p. 223), sendo que tal reminiscência pode ser uma imagem daquele momento.

Didi-Hubermann (2011), na esteira de Benjamin, destaca que "o primeiro operador político de protesto, de crise, de crítica ou de emancipação, deve ser chamado imagem, no que diz respeito a algo que se revela capaz de transpor o horizonte das construçôes totalitárias" (DIDI-HUBERMANN, 2011 [2009], p. 118, grifos do autor). Ele, indo ainda mais além, propóe que o sentido da reflexão de Benjamin "sobre o papel da imagens como modo de 'organizar' - isto é, também de desmontar, de analisar, de contestar - o próprio horizonte de nosso pessimismo fundamental” tem uma dimensão crítica produtiva (DIDI-HUBERMANN, 2011 [2009], p. 118). Ao desvelar os sentidos de qualquer imagem sobre a qual decida se debruçar, Didi-Hubermann esmiuça cada detalhe que possa explodir em uma mônada de possibilidades, facilitando a compreensão sobre o contexto imaginado daquele tempo-instante em que, talvez, tenha lampejado um vaga-lume.

Já Kracauer apresenta a ideia de que é possível encontrar "a presença do imprevisível” na imagem fotográfica (KRACAUER, 2014 [1951], p. 79), acrescentando 
que esta pode e deve facilitar a produçáo de conhecimento do historiador, ou seja, deve ser utilizada pela ciência. Em um de seus ensaios, ele afirma que a fotografia "é uma medida de isolar os movimentos e as configuraçóes transitórias que nosso olho seria incapaz de registrar" (KRACAUER, 2014 [1951], p. 62). Ao utilizar imagens fotográficas, ampliamos, pois, a produção de um conhecimento crítico sobre a situação contida na narrativa daquela imagem. É o que faremos a seguir.

\section{IMAGENS DA PRAIA DA ESTAÇÃo}

A primeira imagem que compóe nossa montagem é um registro da marcha do primeiro Eventão da Praia da Estação, organizado em parceria com diversas bandas e com o Duelo de MC's, havendo a realização de uma apresentação musical debaixo do viaduto Santa Tereza (Figura 1). Entre a praça e o viaduto, ambos constantes do conjunto arquitetônico tombado, vemos na imagem uma parte do caminho que os manifestantes estavam quase terminando de percorrer.

Aliás, essa foi a primeira saída da Praça da Estação do movimento, a primeira onda ${ }^{13}$ que transbordou para além da areia da praia. Duas proposiçóes muito importantes para o movimento foram desenvolvidas nesse dia: a primeira era fazer que a praia existisse fora da praça, e a segunda, assumir a marcha como um movimento de produção de sentido coletivo na cidade. A demanda de sair da praça aconteceu, principalmente, por uma razão prática, a impossibilidade de sonorização para as bandas que tocariam no Eventão. Conversando com a equipe do Duelo de MC's, eles nos ensinaram como utilizavam a instalaçấo elétrica embaixo do viaduto nos eventos que realizavam semanalmente nas noites de sexta-feira.

Figura 1: Primeiro Eventáo Praia da Estação, Avenida dos Andradas, 6 de março de 2010

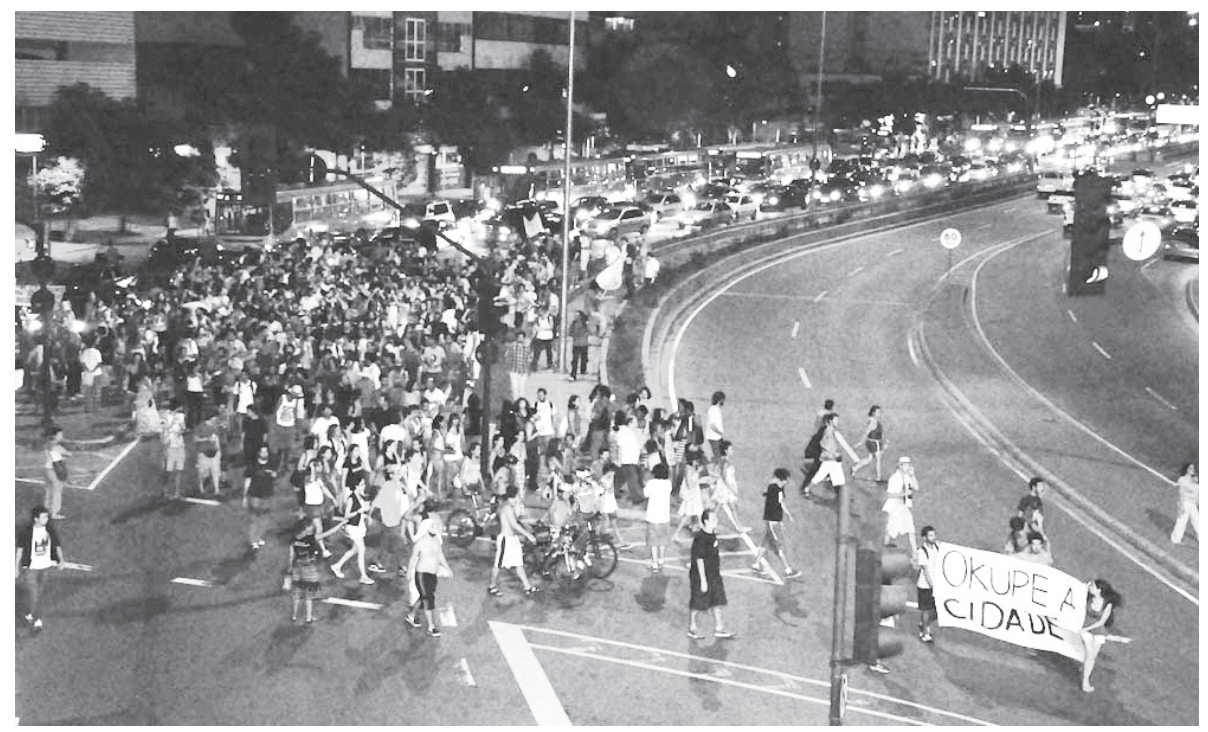

Fonte: Fotografia de Tamás Bodolay (2010).

Com a necessidade da mudança de local, ficou certo para todos os participantes do Eventão que, em algum momento, o deslocamento precisaria ocorrer entre a
13 A ideia de onda perpassa a produção do imaginário praieiro e fez parte dos textos do cartaz chamando para o Eventão, na frase "A onda não acaba na praia" (ABREU, 2013, p. 30). 
Praça da Estaçáo e embaixo do Viaduto Santa Tereza. Terminadas as atividades na praça, alguns banhistas propuseram, então, que o trajeto fosse feito pela Avenida dos Andradas, compondo um texto durante o caminho percorrido na cidade. Segundo a compreensão de Michel de Certeau (2004, [1990]), quando caminhamos na rua, construimos igualmente um discurso que significa (e tem significado) no e com o contexto urbano. Para o autor, a "enunciação pedestre" se constitui na relação entre o estilo e o uso tanto da linguagem quanto do espaço urbano, possibilitando, dessa maneira, uma outra escrita na cidade - a escrita que todos os transeuntes fazem ao percorrer a pé as ruas cotidianamente.

$\mathrm{Na}$ imagem, podemos perceber algumas linhas de luzes de automóveis e ônibus paralisados nos dois lados da avenida. As linhas de trânsito também estáo riscadas e, mesmo na curva, seguem uma linha ordenada. As plantas crescem em jardineiras de concreto, que, semelhantemente, também seguem os traços da avenida. Já a escrita dos passos da marcha indica uma mistura de corpos que foge ao traçado urbanístico, mistura-se e perturba a ordem policial, ao atrapalhar o trânsito de uma tarde de domingo. Destacamos que foi a primeira vez que a praia aconteceu em um outro dia da semana que não o sábado. A ocupação possibilitada pela marcha imprimiu uma escrita que surge nas entrelinhas dos traços definidos pelo planejamento urbano.

Ao decidir fazer a marcha juntos, decidimos escrever algumas outras linhas nas proximidades da Praça Rui Barbosa, já que eventos por lá estavam proibidos. Com a enunciaçáo dos passos dos banhistas que percorreram o asfalto e o concreto sobre o rio Arrudas, quase todo coberto, escrevemos para a cidade que estávamos ali, realmente com o intuito de trazer à tona outros projetos de cidade, entre eles, o de ocupá-la para, assim, atribuir-lhe outros sentidos.

Figura 2: Aniversário de um ano da Praia da Estação, Avenida Amazonas, 23 de janeiro de 2011

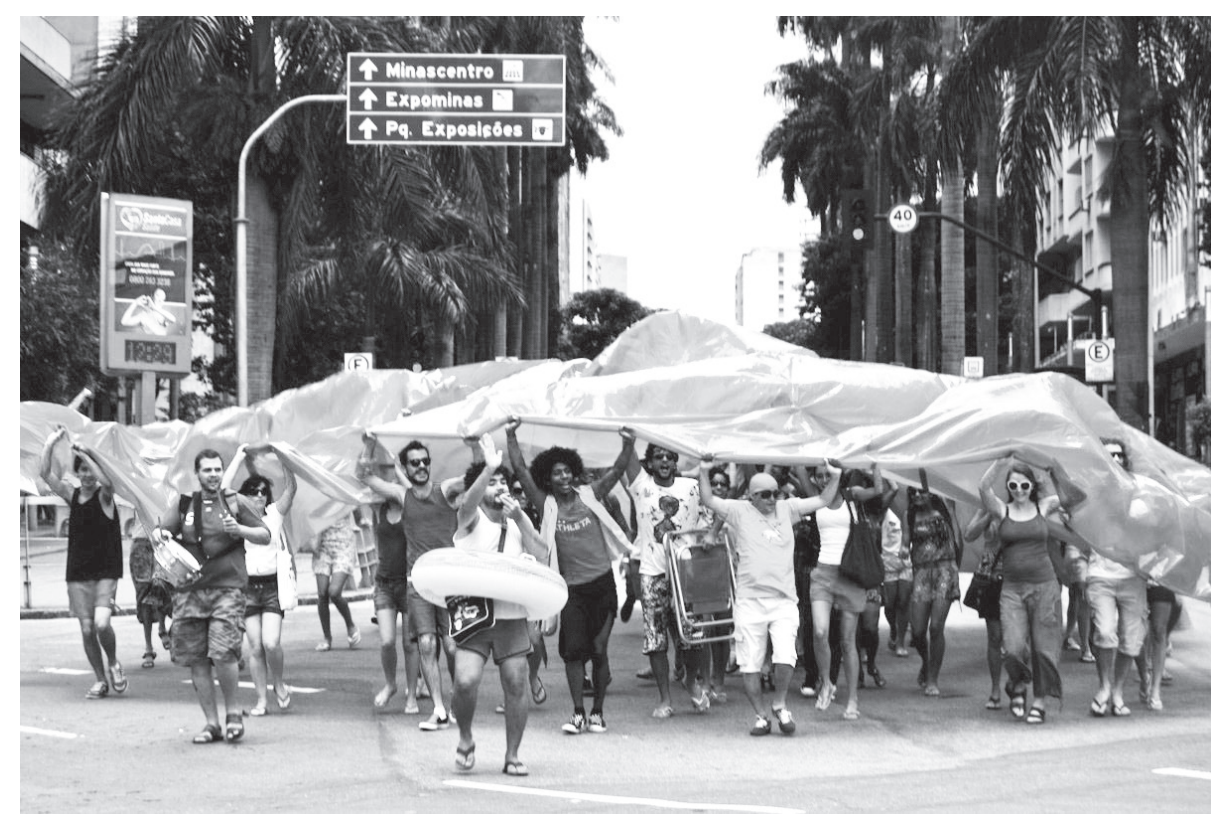

Fonte: Fotografia de Flora Rajão (2011). 
A segunda imagem é a do mar da Praia da Estação, descendo a Avenida Amazonas em direção à praça, no evento de comemoração de um ano da existência da Praia (Figura 2). O mar foi inspirado na obra Divisor (1968), da artista Lygia Pape, encenada pela primeira vez com crianças de uma escola localizada em uma favela carioca, em plena ditadura militar. Em uma entrevista em 2004, a artista disse que gostaria que o trabalho fosse coletivo e que pudesse acontecer outras vezes, sem que ela estivesse presente, participando da produção dos sentidos atualizados pela obra - açôes que "atualmente são chamadas de performances"14. Composta por um pano branco de algodáo de 20 x 20 metros e com fendas, Divisor foi diversas vezes reencenada, sendo que em 2010 foi apresentada em um vídeo (de uma outra encenação feita na década de 1990 no Rio de Janeiro) na 29 Bienal de Arte de São Paulo. Belo Horizonte recebeu, logo na sequência, uma mostra de extensão da Bienal de Arte, com a exposição de algumas obras no Palácio da Artes, centro cultural estadual, gerido pela Fundação Clóvis Salgado. Entre as atividades, para além da exposição, estava prevista a reencenação da obra de Lygia Pape. Foi organizada, para tanto, uma reunião, porém esta não foi aberta a todos os presentes que nela se apresentaram; a participação foi restrita a jovens participantes de um projeto de serviço social e de formação artístico-cultural do Estado.

Sentindo-se lesados por náo terem a possibilidade de participar da proposiçáo, alguns dos banhistas da Praia da Estação que lá estavam presentes resolveram propor a produção de uma réplica da obra para os outros membros da lista de e-mail. Convocaram uma reuniáo em uma outra praça da cidade, localizada aos pés da zona do Curral, a Praça Juscelino Kubitscheck, onde os que estivessem interessados estariam convidados a comparecer para ajudar a produzir o que já se chamava de "mar da Praia da Estação". Inspirado no Divisor, esse mar foi produzido em plástico azul.

Esse segundo deslocamento das atividades da praia para outra praça possibilitou contatos com pessoas diferentes do público que circula no centro da cidade e, consequentemente, ampliou o desenho dos limites da Praia. A proximidade com a Vila Acaba Mundo $^{15}$ e com os apartamentos luxuosos de uma das áreas nobres da cidade - a Avenida Bandeirantes - garantiu um dia de trabalho permeado por encontros com muitas crianças, tanto com as da favela, que circulavam livres pela área, como com aquelas que eram acompanhadas pelas babás:

A saída do mar foi chamada na lista de e-mails da praia como atividade do Eventáo de um ano, e desceu da Praça Sete em direção à praia pela Avenida Amazonas, com as pessoas cantando acompanhadas por um tarol, inventando danças e parando o trânsito movimentado do centro, no sábado pela manhã. Chegando, o mar foi direto para a fonte, e a pressão dos jatos de água formaram condições de possibilidades de criaçóes de brincadeiras, negociadas entre os corpos vestidos em trajes de banho, no concreto. Logo, o mar estava no chão e os banhistas escorregavam sobre ele, junto com as outras pessoas que vieram se misturar naquele momento, como no vídeo compartilhado no mesmo dia, https://www.youtube.com/watch?v=GpqS2pfXfVY (MIGLIANO, 2014, p. 125).

A realização da performance com a réplica/inspiração de Lygia Pape ampliou a maneira de se relacionar com a cidade. A dimensão lúdica e contagiante do protesto-lúdico-festivo perpassou a potência estética na apropriação de uma obra de uma artista implicada nas lutas políticas e históricas, atualizando o imaginário praieiro na
14 Disponivel em: <http:// www.lygiapape.org.br/>. Acesso em: 31 ago. 2015.

15 Em Belo Horizonte os aglomerados urbanos construídos em condições precárias de ocupação e baseados em arquitetura vernacular, conhecidos como favelas em todo o Brasil, são chamados de vilas. 
prática. Na imagem, ainda podemos notar a dimensão de criação dos banhistas participantes, quando desvestem o mar e, juntos, fazem vibrar o azul, com os braços estendidos para o alto, simulando as ondas de um mar imaginado.

Se a enunciação pedestre produzida coletivamente na marcha do primeiro Eventão foi uma situação importante para a onda da praia, o mar foi a conquista da estratégia de produção tática de ondas. Ao considerar que a tática é o modo de usar de quem não tem o poder estratégico para agir, estamos seguindo a dimensão de produção de sentidos da enunciação pedestre de Certeau (2004 [1990]). A potência da arte na produção de agenciamentos coletivos de enunciação, acessando e acionando afetos e perceptos por meio da "contaminação transversal afetiva" (GUATTARI, 2012 [1992], p. 116), pode explicar a força da imagem do mar para os banhistas mineiros, que estavam ali performando a agência de transformação daquele espaço. O agenciamento coletivo de enunciação (DELEUZE; GUATTARI, 2011 [1980]) produzido aqui ultrapassa a dimensão da criatividade cotidiana, pois transforma a ordem policial dos espaços legitimados, inclusive, pela arte. Felix Guattari afirma que, quando a produção simbólica passa pela dimensão sensível, o desejo de se "excentrar em relação aos quadros e coordenadas pré-formadas" (GUATTARI, 2012 [1992], p. 116) se amplia ainda mais em todos os que são afetados pela produção em questão. Transformar as coordenadas e quadros, tanto da realidade social urbana quanto do mundo da arte, muitas vezes exclusivo aos círculos que interessam aos que têm o poder sobre a sua legitimidade, era, sem dúvida, uma das motivaçóes dos participantes do Eventão de um ano da Praia.

Relevante para os banhistas, mas também para a mídia local e para as redes alternativas de comunicação conectadas pela Internet, a imagem do mar chegando à Praia da Estação expandiu o alcance do imaginário praieiro. Quando a figura 2 foi publicada nos jornais impressos e na Internet e, posteriormente, em revistas, ela foi vista por muitas pessoas que não estiveram no momento presente da performance. Um grupo do carnaval de rua do Rio de Janeiro - que a cada ano muda seu percurso e o nome do cortejo, numa tática política de fuga do ordenamento determinado - fez ainda, naquela semana, um convite ao mar belo-horizontino para participar do seu desfile, que se chamaria "O centrão vai virar mar". A Internet começava a fazer sentido para além das ruas de Belo Horizonte, conectando a Praia da Estação a outros portos.

A terceira imagem é a do Bloco da Praia da Estação realizando a lavagem simbólica das escadarias da Prefeitura de Belo Horizonte (Figura 3). A prática cultural da lavagem de escadarias de igrejas acontece principalmente nas festas de largo na Bahia, como a Festa do Nosso Senhor do Bonfim. Todo começo de ano, as baianas, vestidas com trajes típicos de suas atuações em terreiros de candomblé, realizam uma procissão da Igreja de Nossa Senhora da Conceição da Praia até a Igreja do Nosso Senhor do Bonfim, na Ribeira, em Salvador. Ao chegarem às escadas do bonfim, jogam a água perfumada por lavanda que traziam em seus baldes e varrem a sujeira, que simboliza os pensamentos negativos, abrindo espaço para os bons caminhos do novo ano. No caso de Belo Horizonte, a demanda era lavar todas as corrupçóes e os desmandos do atual prefeito, para que a cidade pudesse seguir inspirada em outras experiências, como as do tempo em que o Orçamento Participativo acontecia em reuniōes públicas nos bairros da cidade. 
Figura 3: Lavagem das escadarias da Prefeitura de Belo Horizonte pelo Bloco da Praia da Estação, Avenida Afonso Pena, 5 de março de 2011

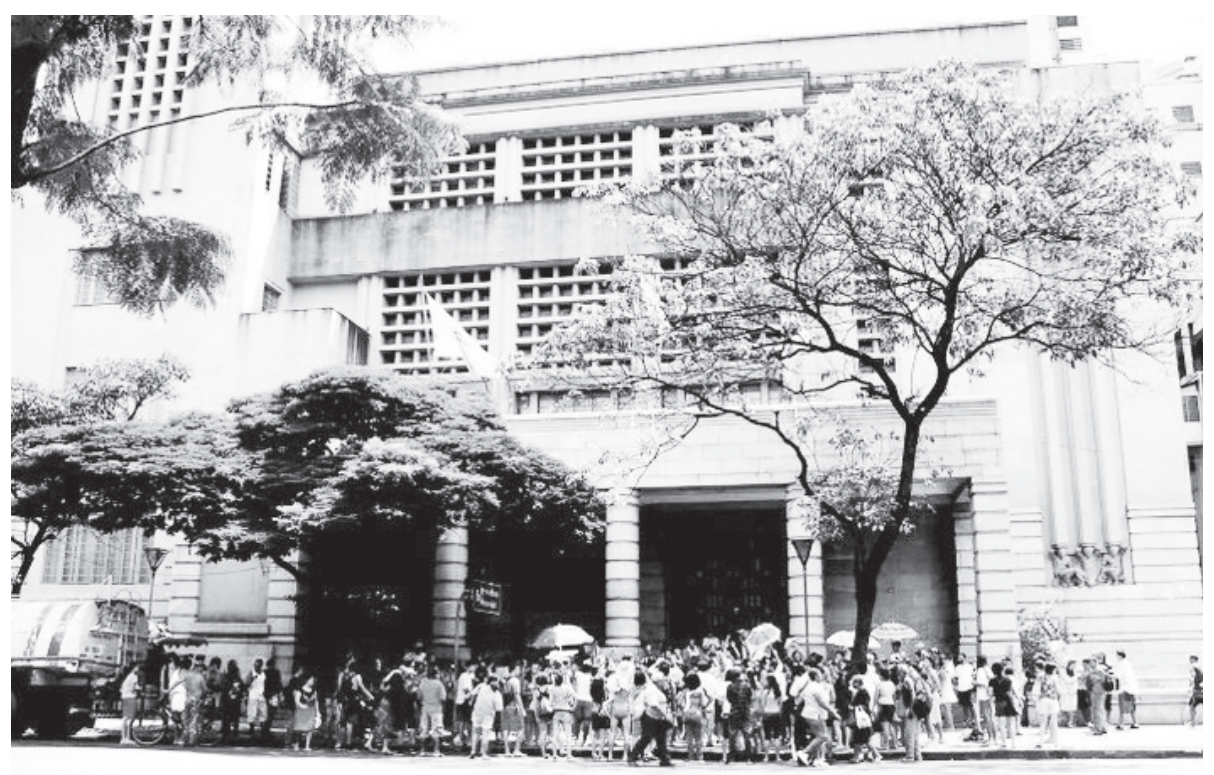

Fonte: Fotografia de Flávia Mafra (2011).

$\mathrm{Na}$ imagem, vemos o caminhão-pipa estacionado, as pessoas vestidas em trajes de banho, portando acessórios de praia como parte da fantasia do bloco. Os guardas municipais, em uniformes escuros na escadaria, e a monumentalidade e dureza do prédio da prefeitura contrastam-se com a volumetria da massa de foliôes ao pé do prédio.

Notamos, ainda, ao menos três pessoas que passam pela rua, observando o bloco, fazendo um outro uso da rua, o de lugar de passagem cotidiana. Talvez os banhistas-foliōes estivessem cantando a marchinha da Praia da Estação: "fui me banhar na Praia da Estação/ mas esqueci o filtro solar/ agora saio no bloco do Tchatcha/ fantasiado de camarão/ tenho certeza que valeu a pena/ é um absurdo o tal decreto/ se o Lacerda curte a canetada/ que dê uma canetada no próprio reto"16.

O imaginário praieiro também chegou até a crítica política por meio do samba de uma marchinha de carnaval. Outros blocos vieram, por diversos bairros, transformando a tradicional fuga da cidade para outros estados ou mesmo para o interior no feriado pagão. Dois anos mais tarde, a festa já estava tão animada que chamou a atenção de emissoras de televisão e do Poder Público. No ano seguinte, além dos banheiros químicos que a prefeitura já havia passado a distribuir, foi preciso que os blocos dissessem se aceitariam ou não a divulgação da prefeitura, cláusula exigida diante da publicidade que estava sendo feita a partir das imagens produzidas nos blocos. Atualmente, a prefeitura tem desenvolvido um plano de apoio e de publicização da festa que tem atraído multidóes, a qual já faz parte do calendário festivo da Secretaria de Turismo do Poder Municipal. Uma das grandes discussões entre os foliôes e a secretaria é a da dimensão de manifestação cultural do carnaval, em vez do entendimento da festa como um evento turístico pontual.

Contudo, existem outras apropriaçôes de todo esse imaginário praieiro que, com ludicidade e posicionamento político, vem contaminando outros movimentos de
16 De autoria de um dos banhistas, a marchinha encontra-se gravada no disco, disponível online, Deita no cimento! Músicas do carnaval de rua de Belo Horizonte 2009-2014. 
17 Existem diversas ocupações urbanas em Belo Horizonte organizadas por movimentos sociais, as quais estão em constante diálogo e luta com a prefeitura, diante da necessidade de legalizarem sua existência como novos bairros já estruturados. O tema é amplo; tomamos aqui apenas uma situação para demonstrar a amplitude do imaginário praieiro, acessado em outras reivindicações urbanas.

18 A \#ocupação é o nome de um evento - prática de tomada de um espaço público - que surgiu em Belo Horizonte logo após as Jornadas de Junho de 2013, que saíram às ruas das capitais brasileiras. Organizadas em grandes assembleias populares, de modo descentralizado e sem líderes, foram uma maneira encontrada pelos manifestantes de perpetuar a visibilidade de sua indignação diante das injustiças sociais na capital mineira, tematizando, mensalmente, questões importantes a serem tratadas. A \#ocupação $n^{\circ} 8$ foi realizada em uma ocupação urbana em luta por moradia, pondo em questão a importância de o Poder Público atentar-se para e solucionar o deficit de habitação para a população carente. reconquista de espaços públicos, como o Ocupe Estelita, em Recife, o Ocupe a Estação, em São Félix, entre outras açóes. Conhecendo a ação pelas narrativas disponibilizadas na Internet e, quando possível, pelas trocas presenciais entre os manifestantes, a ocupação do espaço dos prédios abandonados que serviam à rede ferroviária em Recife e São Félix foi motivada também pelas táticas e práticas da Praia da Estação: a revisão do decreto, liberação dos eventos na Praça da Estação, assim como a implementaçáo da lei da Praça Livre podem ser entendidas como vitórias dos banhistas belo-horizontinos. No caso do Ocupe Estelita, a luta contra a espetacularização (JACQUES, 2004) da especulação imobiliária é também um forte ponto em comum entre as ocupaçôes mineira e pernambucana. Em São Félix, a luta é para que o espaço abandonado, após um esquema de corrupçáo de uma fundaçấo de caridade, volte a ter utilidade pública, antes que o tempo transfome todo o prédio em apenas uma ruína.

Ainda existem muitas batalhas e lutas a serem travadas por conta das divergências de interesses entre o poder urbanístico e as necessidades e desejos da população em Belo Horizonte. A situaçáo das ocupaçóes urbanas ${ }^{17}$, com suas respectivas ordens de despejo, é uma delas. Em agosto de 2014, o evento \#ocupação $n^{\circ} 8^{18}$ aconteceu na ocupação urbana Isidoro: em uma das chamadas feitas no Facebook para que as pessoas comparecessem a ele, foi republicado o teaser da Praia da Estação. O imaginário praieiro foi atualizado mais uma vez, publicizado com o intuito de motivar a ação de luta e festa naquele fim de semana.

As \#ocupação(ôes) também são, em alguma medida, inspiradas pela prática da Praia. A primeira delas ocorreu logo depois das manifestações das Jornadas de Junho de 2013, nas quais dois rapazes, vítimas da violência policial em Belo Horizonte, morreram. Na sequência da primeira edição da ocupaçáo, realizada na parte de baixo do viaduto Santa Tereza, os participantes organizaram uma marcha e seguiram até a Câmara Municipal, onde acamparam e lá permaneceram por mais de 40 dias, protestando contra a máfia do transporte público, o atraso na revelação dos dados das contas públicas, a violência policial. Mas isso é assunto para outros textos.

Figura 4: Recorte de mapa do Centro de Belo Horizonte contendo os trajetos realizados nas três situaçóes narradas pelas imagens

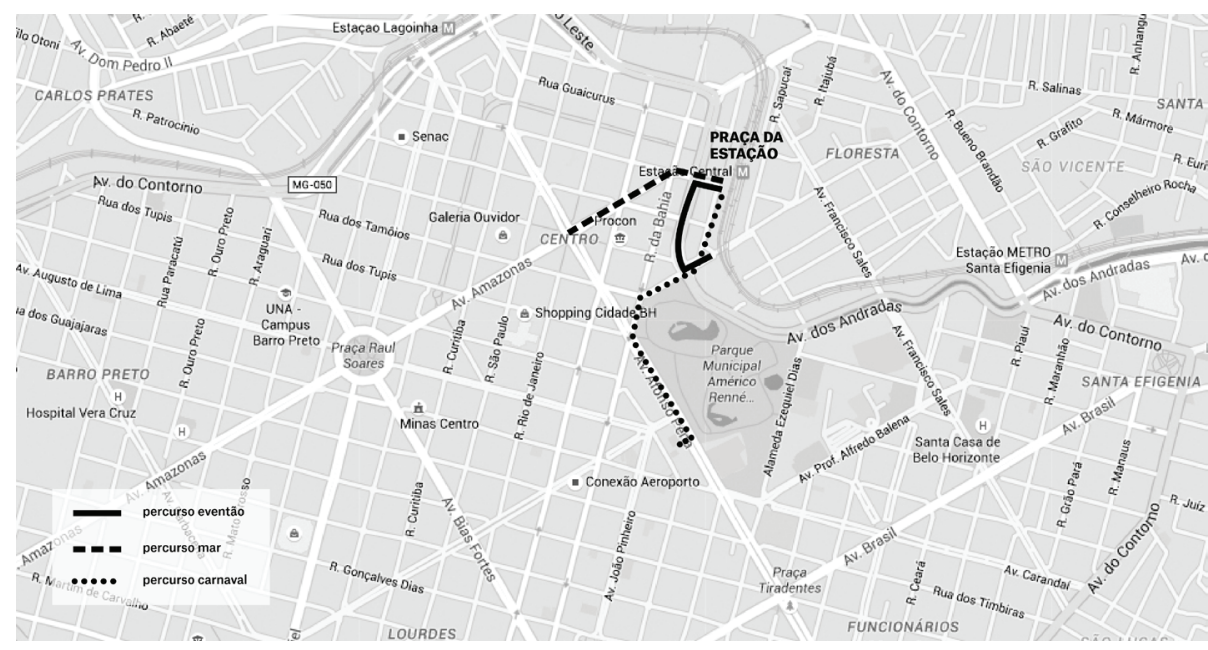

Fonte: Produção da autora. 


\section{ATUALIZAÇÕES}

Consideramos como narrativa a produção de imaginários compartilhados sobre a situação de experiência. Usamos como matéria-prima da montagem entrevistas, conversas e encontros, bem como textos e imagens das práticas que foram compartilhadas tanto em copresença espacial quanto por meio de mediação digital. Levamos em conta os processos relatados pelos cidadãos implicados no desejo, visibilidade e reinvindicação dos espaços urbanos em questão.

Podemos, agora, com a breve análise crítica que esboçamos, perceber que é possível inventar, produzir e compartilhar outros projetos de cidade, fazer uso dos espaços físicos e virtuais nos processos de ocupaçáo e reivindicaçáo da urbanidade, produzindo imaginários políticos diferenciados. Encontrar a potência de produzir contaminaçôes e redes e imbricar outras pessoas e outras cidades em práticas de criticar/desejar/fazer outra cidade são algumas das outras sociabilidades contra-hegemônicas que emergem da Praia da Estação. Fazem parte dessas redes de sentidos as narrativas híbridas, produzidas, muitas vezes, com o uso das novas tecnologias de comunicação e informação e compartilhadas no espaço urbano e na Internet.

Observamos na montagem a potência crítica da Praia da Estação na produção de outros imaginários políticos e urbanos, reinventando o uso do modelo de ocupação urbana, de sociabilidade na cidade, e buscando outros modos de apropriação do espaço virtual da Internet.

A partir da ampliação de temporalidades em cada uma dessas situaçóes, as condiçôes de possibilidade de experiências a serem mobilizadas também se expandiram. Quando outros tempos se atualizam no mesmo território da praça Rui Barbosa, percebemos que a Praia da Estação permite a composição coletiva de recriaçôes de rituais cotidianos, políticos, religiosos, populares e artísticos, bem como de rituais que ainda estão por vir. Essas experiências são apreendidas por narrativas em imagens, vídeos, músicas e textos produzidos colaborativa e compartilhadamente, na espera dos desenrolares, dos acasos e imprevistos. É essa capacidade de não saber ao certo o que pode vir a acontecer, mas confiando, praticando e atualizando as experiências que já aconteceram, que cria, nesses tempos de ocupação, outros imaginários políticos possíveis.

\section{REFERÊNCIAS BIBLIOGRÁFICAS}

ABREU, C. A. Ei, polícia, a praia é uma delícia!: rastros de sentidos nas conexóes da Praia da Estação. 2013. Dissertação (Mestrado em Comunicação) - Faculdade de Filosofia e Ciências Humanas, Universidade Federal de Minas Gerais, Belo Horizonte, 2013.

BENJAMIN, W. Obras Escolhidas Vol. I - Magia e Técnica, Arte e Política. São Paulo: Brasiliense, 1996 [1940].

Obras Escolhidas Vol. II - Rua de Mão Única. São Paulo: Brasiliense, 2000 [1928]. Capitalismo como religião. São Paulo: Boitempo Editorial, 2013 [1925].

CERTEAU, M. A invenção do cotidiano. Petrópolis: Vozes, 2004 [1990].

CESÁRIO, L. L. Debaixo do viaduto tem um Duelo de MC's. Revista Marimbondo, Belo Horizonte, v. 1, 2011. Disponível em <http://revistamarimbondo.com.br/artigo/16>. Acesso em: 20 jun. 2016.

\begin{abstract}
Milene Migliano é graduada e mestra em Comunicação Social pela Universidade Federal de Minas Gerais (UFMG); doutoranda em Arquitetura e Urbanismo pela Universidade Federal da Bahia (UFBA).

E-mail: milenemigliano2@ gmail.com

Artigo recebido em 31 de agosto de 2015 e aprovado para publicação em 7 de dezembro de 2015.
\end{abstract}


DELEUZE, G.; GUATTARI, F. Mil Platôs, Capitalismo e Esquizofrenia, vol. I. São Paulo: Ed. 34, 2011 [1980].

DIDI-HUBERMAN, G. Sobrevivência dos vaga-lumes. Belo Horizonte: Ed. UFMG, 2011 [2009].

GUATTARI, F. Caosmose: um novo paradigma estético. Rio de Janeiro: Ed. 34, 2012 [1992].

JACQUES, P. B. Espetacularização Urbana Contemporânea. Cadernos PPG-AU, Salvador, no especial, 2004. Disponível em: <http://www.portalseer.ufba.br/index.php/ppgau/ article/view/1684>. Acesso em: 10 maio 2016.

KRACAUER, S. Sur le seuil du temps: Essais sur la photographie. Paris: Éditions de la Maison des sciences de l'homme, 2014 [1951].

MARQUES, Â. C. S. Relaçóes entre comunicação, estética e política: tensóes entre as abordagens de Habermas e Rancière. Revista Compolitica, Rio de Janeiro, n. 2, v. 1, p. 110-130, set./out. 2011. http://dx.doi.org/10.21878/compolitica.2011.1.2.28

- Três bases estéticas comunicacionais da política: cenas de dissenso, criação do comum e modos de resistência. In: ENCONTRO NACIONAL DA COMPÓS, 21., 2012. Anais... Juiz de Fora: UFJF, 2012. p. 1-14. Disponível em: <http://www.compos. org.br/data/biblioteca_1830.pdf>. Acesso em: 20 jun. 2016.

MELO, T. M. Praia da Estação [manuscrito]: carnavalização e performatividade. 2014. Dissertação (Mestrado em Artes) - Escola de Belas Artes, Universidade Federal de Minhas Gerais, Belo Horizonte, 2014.

MIGLIANO, M. O Dissenso do Divisor enquanto mar. In: CORPOCIDADE, 4., 2014. Caderno de Articulacoes Corpocidade 4. Salvador: Plataforma Corpocidade, 2014. p. 124-125.

NEGT, O. L'espace public oppositionnel. Paris: Editions Payot et Visage. 2007.

OLIVEIRA, I. T. M. Uma "Praia" nas Alterosas, uma "antena parabólica" ativista: configurações contemporâneas da contestação social de jovens em Belo Horizonte. 2012. Dissertação (Mestrado em Educação) - Faculdade de Educação, Universidade Federal de Minhas Gerais, Belo Horizonte, 2012.

RANCIÈRE, J. O desentendimento: Política e Filosofia. São Paulo: Ed. 34, 1996.

RIBEIRO, A. C. T. Nós temos hoje uma espécie de contenção do imaginário político. Revista Marimbondo, Belo Horizonte, v. 1, 2011. Disponível em <http://revistamarimbondo. com.br/artigo/25>. Acesso em: 20 jun. 2016.

RODRIGUES, R. L. Architecto moderno na cidade: traços e rastros de Luiz Olivieri em Belo Horizonte. 2012. Tese (Doutorado em História) - Faculdade de Filosofia e Ciências Humanas, Universidade Federal de Minas Gerais, Belo Horizonte, 2012.

SENNET, R. Juntos. Rio de Janeiro: Record, 2012. 